\title{
Standards for college libraries, 1985
}

\author{
Prepared by the College Library Standards Committee \\ Jacquelyn M. Morris, Chair
}

\section{This draft will be presented to the ACRL Board and to the library profession at Annual Conference in Chicago.}

\begin{abstract}
$\mathbf{T}$ he Standards for College Libraries were first prepared by a committee of ACRL, approved in 1959, and revised in 1975. This draft was prepared by ACRL's Ad Hoc College Library Standards Committee. Members are Jacquelyn M. Morris, University of the Pacific (chair); B. Anne Commerton, State University of New York at Oswego; Brian D. Rogers, Connecticut College; Louise S. Sherby, Columbia University; David B. Walch, California Polytechnic State University; and Barbara Williams-Jenkins, South Carolina State College.
\end{abstract}

\section{Foreword}

If approved as policy by the Board of Directors of the Association of College and Research Libraries, these Standards will supersede the 1975 "Standards for College Libraries" (C\&RL News, October 1975, pp.277-79, 290-301).

The purpose of publishing the revised Standards in draft form is to give the library profession an opportunity to comment on the proposed changes to the 1975 document. The ACRL Ad Hoc College Library Standards Committee encourages the library profession to review the following document and communicate its reactions to the Committee in one or both of the following ways:

1) Attend the hearings to be held at the Annual ALA conference in Chicago on July 7, 1985, from 2:30-5:30 p.m. Location: Mars Room, Holiday Inn City Centre.

2) Send written comments by June 28 to: Jacquelyn M. Morris, Chair, Ad Hoc College Library
Standards Committee, UOP Libraries, University of the Pacific, Stockton, CA 95211.

The Ad Hoc Committee was appointed in 1982 to examine the 1975 College Library Standards with particular attention to the following areas:

a. Non-print collections and services;

b. Collections (Formula A), Staff (Formula B), and Budget ( $\%$ of Education \& General);

c. Networking and cooperative associations; and to recommend revisions which will bring them up to date and make them more generally useful.

The Committee studied each standard in terms of the charge and reviewed several recent studies on the subject of Standards, including:

Larry Hardesty and Stella Bentley, The Use and Effectiveness of the 1975 Standards for College Libraries: A Survey of College Library Directors (1981).

Ray L. Carpenter, "College Libraries: A Comparative Analysis in Terms of the ACRL Standards," College \& Research Libraries 42 (January 1981):7-18.

"An Evaluative Checklist for Reviewing a College Library Program, Based on the 1975 Standards for College Libraries," C\&RL News, November 1979 , pp. 305-16.

The Committee also published a call for comments on the 1975 Standards (CむRL News, December 1983) and held hearings at the 1984 ALA Midwinter conference. Over 35 people attended these hearings and addressed various issues related to the Standards.

One of the primary issues with which the Com- 
mittee has dealt is the effect of new technology on the Standards. While no one predicts the immediate demise of books as we know them, one cannot ignore the multiplicity of formats in which information appears. For example, will the emerging body of online reference tools eventually make it possible for libraries to provide comparable or improved service with smaller book collections?

Access to the major bibliographic utilities is another issue related to technology and libraries. In an information-rich society, does lack of access to these utilities have a detrimental effect on the scholarly programs college libraries are attempting to support? How should the Standards address this concern?

A related issue centers on resource sharing and networking. Through access to the emerging "National Database," (defined as the totality of OCLC, RLIN, WLN, and LC) we have greatly increased our knowledge of other libraries' collections. Online identification and location of needed material has shortened the retrieval time. Electronic mail will have a similar impact on resource sharing. Since even the largest libraries find it difficult to collect comprehensively, resource sharing has become an increasingly common fact of life. The 1975 Standards placed a very high value on browsability and immediate access to materials, whereas resource sharing is somewhat contradictory to this concept. On the other hand, cooperative agreements allow for exposure and access to vastly more extensive resources than was hitherto possible.

The Committee discussed extensively the topic of performance measures. While the library directors surveyed and reported in the Hardesty-Bentley article stressed the need for performance measures in the College Library Standards, the Committee concluded that providing them at this point is beyond the scope of its charge. Obviously, however, this is a concept whose time has come: the ACRL Task Force on Performance Measures appointed by Carla Stoffle and chaired by Robert Burns has been succeeded by a new committee, appointed by Sharon Rogers, to take action on the recommendations of the Task Force. This Ad Hoc Committee on Performance Measures for Academic Libraries, chaired by Virginia Tiefel, has received a five-year appointment which gives some indication of the complexity of the task. The library profession should monitor and support the work of this new committee.

Some sentiment has been expressed for standards with less emphasis on quantitative measures, patterned after the more abstract "Standards for University Libraries" (C\&RL News, April 1979, pp.101-10). While there are certain advantages to standards written in this way, the vast majority of those expressing opinions to the Committee supported the quantitative measurements provided for in the College Library Standards. Most who expressed this view cited Carpenter's findings, noting that a very large percentage of college libraries fail to meet minimum standards in terms of collection size, staff size or budget. Consequently, prescribed goals continue to be regarded by librarians as an important component of the Standards.

While many statements have been modified in these Standards, certain important points should be noted. For example, while the 1975 Standards addressed collection size, they did not address serial subscriptions, on which it is not unusual now for a library to spend half or more of its annual materials budget. Each Standard has been reviewed in the light of library technology, networking and resource sharing, and audiovisual materials. The inclusion of these aspects of libraries has been addressed in almost every standard. For example, AV materials have been addressed in Standard 2, Collections; Standard 3, Organization of Material; Standard 6, Facilities; and Standard 8, Budget.

\section{Introduction to the standards}

Libraries have long been considered an integral and essential part of the educational programs offered by colleges. Their role has included collecting the records of civilization and documentation of scientific pursuit. An equally important role is to offer various programs to teach or assist users in the retrieval or interpretation of these records and documents. These information resources are essential for members of the higher education community to pursue their academic programs successfully. Total fulfillment of these roles is, however, an ideal goal which continues to be sought and is yet to be attained. Expectations as to the degree of success in achieving this goal vary from institution to institution, and it is this diversity of expectations that prompts the library profession to offer standards for college libraries.

The Standards seek to describe a realistic set of conditions which, if met, will provide an adequate library program in a college. Every attempt has been made to synthesize and articulate the library profession's expertise and views of what constitutes adequacy in a library's budget, resources, services, facilities, administration, staffing, and organization.

These Standards are intended to apply to libraries supporting academic programs at the bachelor's and master's degree levels. They may be applied to libraries at universities which grant a small number of doctoral degrees, say, fewer than ten per year. They are not designed for use in two-year colleges, larger universities, or independent professional schools.

The eight sections of the 1975 College Library Standards have been retained, and include:

1. Objectives

2. Collections

3. Organization of Materials

4. Staff

5. Services 


\section{Facilities}

7. Administration

8. Budget

Each standard is followed by commentary intended to amplify its intent and assist in its implementation.

Whenever appropriate, the terminology and definitions in the ANSI Z39.7 Standards published in 1983 have been used.

\section{Standard 1: Objectives}

1 The college library shall develop an explicit statement of its objectives in accord with the goals and purposes of the college.

\section{Commentary}

The administration and faculty of every college have a responsibility to examine the educational program from time to time in light of the goals and purposes of the institution. Librarians share this responsibility by seeking ways to provide collections and services which support those goals and purposes. Successful fulfillment of this shared responsibility can best be attained when a clear and explicit statement of library objectives is prepared and promulgated so that all members of the college community can understand and evaluate the appropriateness and effectiveness of the library program.

1.1 The development of library objectives shall be the responsibility of the library staff, in consultation with members of the teaching faculty, administrative officers, and students.

\section{Commentary}

The articulation of library objectives is an obligation of the librarians, with the assistance of the support staff. In developing these objectives the library should seek in a formal or structured way the advice and guidance of its primary users, the faculty and students, and of the college administration, in particular those officers responsible for academic programs and policies.

1.2 The statement of library objectives shall be reviewed periodically and revised as necessary.

\section{Commentary}

In reviewing the objectives of the library, careful attention should be paid to ongoing advances in the theory and practice of librarianship. Similarly, changes occurring within the education program of the parent institution should be reflected in a timely way in the program of the library.

\section{Standard 2: The collections}

2 The library's collections shall comprise all types of recorded information, including print materials in all formats, audiovisual materials, sound recordings, materials used with computers, graph- ics, and three-dimensional materials.

\section{Commentary}

The records of intellectual behavior appear in a wide range of formats. Books represent extended reports of scholarly investigation, compilations of findings, creative works, and summaries prepared for instructional purposes. The journal communicates more recent information and is particularly important to the science disciplines. Reports in machine-readable form are an even faster means of research communication. Government documents transmit information generated by or at the behest of official agencies, and newspapers record daily activities throughout the world.

Many kinds of communication take place primarily, or exclusively, through such media as films, slide-tapes, sound recordings, and videotapes. Microforms are used to compact many kinds of information for preservation and storage. Recorded information also exists in the form of manuscripts, archives, databases, and computer software packages. Each medium of communication transmits information in unique ways, and each tends to complement the others.

The inherent unity of recorded information and its importance to all academic departments of an institution require that most, if not all, of this information be selected, organized and made available for use by the library of that institution. In this way the institution's information resources can best be articulated and balanced for the benefit of all users.

2.1 The library shall provide as promptly as possible a high percentage of the materials needed by its users.

\section{Commentary}

While it is important that a library have in its collection the quantity of materials called for in Formula A, its resources may be augmented with an interlibrary loan service and, when feasible, by reciprocal-use arrangements with nearby institutions. A library that meets part of its responsibilities in these ways must ensure that such sharing of resources does not weaken a continuing commitment to develop its own holdings. There is no substitute for a strong, immediately accessible collection. Moreover, once a collection has attained the size called for by this formula, its usefulness will soon diminish if new materials are not acquired at an annual gross growth rate of from two to five percent.

The proper development of a collection includes concern for quality as well as quantity. A collection may be said to have quality for its purposes only to the degree that it possesses a portion of the bibliography of each discipline taught, appropriate in quantity both to the level at which each is taught and to the number of students and faculty members who use it. While it is possible to have quantity without quality, it is not possible to have quality without quantity defined in relation to the charac- 
teristics of the institution. No easily applicable criteria have yet been developed, however, for measuring quality in library collections.

The best way to preserve or improve quality in a college library collection is to adhere to rigorous standards of discrimination in the selection of materials to be added, whether as purchases or gifts. The collection should contain a substantial portion of the titles listed in standard bibliographies for the curricular areas of the institution and for supporting general fields of knowledge. Subject lists for college libraries have been prepared by several learned associations, while general bibliographies such as Books for College Libraries are especially useful for identifying important retrospective titles. A majority of the appropriate, current publications reviewed in scholarly journals and in reviewing media such as Choice and Library Journal should be acquired. Careful attention should also be given to standard works of reference and to bibliographical tools which describe the broad range of information sources.

Institutional needs for periodical holdings vary so widely that a generally applicable formula cannot be used, but in general it is good practice for a library to own any title that is needed more than six times per year. Several good lists have been prepared of periodical titles appropriate or necessary for college collections. Katz's Magazines for Libraries describes 6,500 titles, of which approximately ten percent may be regarded as essential to a broad liberal arts program for undergraduates. To this estimate must be added as many titles are deemed necessary by the teaching faculty and librarians to provide requisite depth and diversity of holdings. It may not be necessary to subscribe to certain less frequently used titles if they are available at another library nearby, or if needed articles may be quickly procured through a reliable delivery system or by electronic means.

The library collection should be continually evaluated against standard bibliographies and evolving institutional requirements for purposes both of adding new titles and identifying for withdrawal those titles which have out-lived their usefulness. No title should be retained for which a clear purpose is not evident in terms of academic programs or extra-curricular enrichment.

Although the scope and content of the collection is ultimately the responsibility of the library staff, this responsibility can be best fulfilled by developing and maintaining a written policy in cooperation with the teaching faculty. Moreover, the teaching faculty should be encouraged to participate in the selection of new titles for the collection.

\subsection{The amount of print material to be provided} by the library shall be determined by a formula (See Formula A) which takes into account the nature and extent of the academic program of the institution, its enrollment, and the size of the teaching faculty. The relationship of audiovisual collections and resource sharing activities to print collection size should be taken into account.

\section{Commentary}

\section{A. Print Resources}

A strong core collection of print materials, augmented by specific allowances for enrollment, faculty size, and curricular offerings, is an indispensable requirement for the library of any college. The degree to which a library meets this requirement may be calculated with Formula A.

\section{B. Audiovisu al resources}

The range, extent and configuration of nonprint resources and services in college libraries varies widely according to institutional needs and characteristics. Although audiovisual materials may constitute an important and sometimes sizable part of a library collection, it is neither appropriate nor

\section{FORMULA A-}

1. Basic collection

2. Allowance per FTE faculty member

3. Allowance per FTE student

4. Allowance per undergraduate major or minor field

5. Allowance per master's field, when no higher degree is offered in the field

6. Allowance per master's field, when a higher degree is offered in the field

7. Allowance per 6 th year specialist degree field

8. Allowance per doctoral field
85,000 vols. 100 vols. 15 vols. 350 vols.

6,000 vols.

3,000 vols.

6,000 vols.

25,000 vols.

A "volume" is defined as a physical unit of a work which has been printed or otherwise reproduced, typewritten, or handwritten, contained in one binding or portfolio, hardbound or paperbound, which has been catalogued, classified, and/or otherwise prepared for use. Microform holdings should be converted to volume-equivalents, whether by actual count or by an averaging formula which considers each reel of microfilm, or five pieces of any other microform, as one volumeequivalent. 
possible to establish a generally applicable prescriptive formula for calculating the number of such items which should be available.

Audiovisual holdings may be counted as Bibliographic Unit Equivalents and combined with the number of print volumes and volume equivalents in measuring a library's holdings against Formula A. These materials include sound recordings, videocassettes, videodisks, films, filmstrips, loops, slides (50 slides $=1 \mathrm{BUE}$ ), slide-tape sets, maps and other graphic material, and computer software packages. If some or all of this material is housed in an administratively separate media center or audio-visual facility, it may be included in the grade determination if properly organized for use and readily accessible to the college community.

\section{ResourCe SHARING}

The extent of resource sharing through formal cooperative arrangements among libraries should be recognized in any assessment of the ability of a library to supply its users with needed materials. Similarly, the use of online databases or other marketed information sources may be included in this assessment. Annual statistics of resource sharing and the use of information services may be compiled for this purpose, as follows:

1. Number of books or other items borrowed via ILL channels.

2. Number of articles acquired from outside sources.

3. Recorded number of items borrowed from a nearby library with which a formal resource sharing arrangement is in effect.

4. Number of online database searches performed.

\section{Total}

\section{Determination of grade}

Libraries which can promptly provide 90 to 100 percent of as many volumes or volume-equivalents as are called for in Section A, augmented with annual statistics from Sections B and C, shall be graded $\mathrm{A}$ in terms of library resources. From 75 to 89 percent shall be graded B; 60 to 74 percent shall be graded $\mathrm{C}$; and 50 to 59 percent shall be graded D.

\section{Standard 3: Organization of materials}

3 Library collections shall be organized by nationally approved conventions and arranged for efficient retrieval at time of need.

\section{Commentary}

The acquisition of library materials comprises only part of the task of providing access to them. Collections should be indexed and arranged systematically to assure efficient identification and retrieval.
3.1 There shall be a union catalog of the library's holdings that permits identification of items, regardless of format or location, by author, title, and subject.

\section{Commentary}

The union catalog should be comprehensive and provide bibliographic access to materials in all formats owned by the library. This can best be accomplished through the development of a catalog with items entered in accord with established national or international bibliographical conventions, such as rules for entry, descriptive cataloging, filing, classification, and subject headings.

Opportunities of several kinds exist for the cooperative development of the library's catalog. These include the use of cataloging information produced by the Library of Congress and the various bibliographic utilities. It may also include the compilation by a number of libraries of a shared catalog. Catalogs should be subject to continual editing to keep them abreast of modern terminology and contemporary practice.

3.1.1 The catalog shall be in a format that can be consulted by a number of users concurrently.

\section{Commentary}

A public catalog in any format can satisfy this Standard if it is so arranged that the library's users normally encounter no delay in gaining access to it. While this is rarely a problem with the card cata$\log$, the implementation of a microform, book, or online catalog requires that a sufficient number of copies (or terminals) be available to minimize delay in access at times of heavy demand.

3.1.2 In addition to the union catalog there shall also be requisite subordinate files to provide bibliographic control and access to all library materials.

\section{Commentary}

Proper organization of the collections requires the maintenance of a number of subordinate files, such as authority files and shelf lists, and of complementary catalogs, such as serial holdings records. Information contained in these files should also be available to library users. In addition, the content of library materials such as journals, documents, and microforms should be made accessible through indexes in printed or computer-based format.

3.2 Library materials shall be arranged to provide maximum accessibility to all users. Certain categories of materials may be segregated by form for convenience.

\section{Commentary}

Materials should be arranged so that related information can be easily consulted. Some materials such as rarities, manuscripts, or archives, may be segregated for purposes of security and preservation. Materials in exceptionally active use, reference works, and assigned readings, may be kept separate as reference and reserve collections to fa- 
cilitate access to them. Audiovisual materials, maps, and microforms, are examples of resources that may be awkward to integrate physically because of form and may need to be segregated from the main collection. Fragmentation of the collections should be avoided wherever possible, however, with the bulk of the collections shelved by subject in open stack areas to permit and encourage browsing.

\subsection{Materials placed in storage facilities shall be} readily accessible to users.

\section{Commentary}

Many libraries or groups of libraries have developed storage facilities for low-use materials such as sets or backruns of journals. These facilities may be situated on campus or in remote locations. The materials housed in these facilities should be easily identifiable and readily available for use in a timely fashion. If direct user access is not possible, a rapid retrieval system should be provided.

\section{Standard 4: Staff}

4 The staff shall be of adequate size and quality to meet the library's needs for services, programs, and collection organization.

\section{Commentary}

The college library shall need a staff composed of qualified librarians, skilled support personnel, and part-time assistants to carry out its stated objectives.

4.1 Librarians, including the director, shall have a graduate degree from an ALA-accredited program, shall be responsible for duties of a professional nature, and shall participate in library and other professional associations.

\section{Commentary}

The librarian has acquired through education in a graduate library and information science school an understanding of the principles and theories of selection, acquisition, organization, interpretation and administration of library resources. Moreover, developments in computer and information technology have had a major impact on librarianship requiring further that librarians be well informed in this developing area.

Librarians shall be assigned responsibilities which are appropriate to their education and experience and which encourage the ongoing development of professional competencies. Participation in library and other professional associations on and off campus is also necessary to further personal development.

4.2 Librarians shall be organized as a separate academic unit such as a department or a school. They shall administer themselves in accord with ACRL "Standards for Faculty Status for College and University Librarians" and institutional policies and guidelines.

\section{Commentary}

Librarians comprise the faculty of the library and should organize, administer, and govern themselves accordingly. The status, responsibilities, perquisites and governance of the library faculty shall be fully recognized and supported by the parent institution.

4.3 The number of librarians required shall be determined by a formula (See Formula B) and shall further take into consideration the goals and services of the library, programs, degrees offered, institutional enrollment, size of faculty and staff, and auxiliary programs.

\section{Commentary}

Formula B is based on enrollment, collection size, and growth of the collection. Other factors to be considered in determining staff size are services and programs, degrees offered, size of the faculty and staff, and auxiliary programs. Examples of services and programs include reference and information services, bibliographic instruction, computerbased services, collection development, and collection organization. In addition, auxiliary programs, e.g., extension, community, and continuing education, as well as size and configuration of facilities, and hours of service, are factors to be considered for staff size.

4.4 The number of FTE support staff required shall be 1.75 per librarian not including student assistants. Support staff and part-time assistants shall be assigned responsibilities appropriate to their qualifications, training, experience and capabilities.

\section{Commentary}

Full-time and part-time support staff carry out a wide variety of paraprofessional, technical, and clerical responsibilities. A productive working relationship between the librarians and the support staff is an essential ingredient in the successful operation of the library. In addition, student assistants provide meaningful support in accomplishing many library tasks.

4.5 Library policies and procedures concerning staff shall be in accord with institutional guidelines and sound personnel management.

\section{Commentary}

The staff represents one of the library's most important assets in support of the instructional program of the college. Its management must be based upon sound, contemporary practices and procedures consistent with the goals and purposes of the institution, including the following:

1. Recruitment methods should be based upon a careful definition of positions to be filled and objective evaluation of credentials and qualifications.

2. Written procedures should be developed in accordance with ACRL and institutional guidelines, and followed in matters of appointment, promotion, tenure, dismissal and appeal. 
3. Every staff member should be informed in writing as to the scope of his/her responsibilities.

4. Rates of pay and benefits of library staff should be equivalent to other positions on campus requiring comparable backgrounds.

5 . There should be a structured program for orientation and training of new staff members, and career development should be provided for all staff.

6. Supervisory staff should be selected on the basis of job knowledge, experience and human relations skills.

7. Procedures should be maintained for periodic review of staff performance and for recognition of achievement.

For references, the following documents may be consulted: "Guidelines and Procedures for the Screening and Appointment of Academic Librarians," C $\& R L$ News, September 1977, pp.231-33; "Model Statement of Criteria and Procedures for Appointment, Promotion in Academic Rank, and Tenure for College and University Librarians," C\&RL News, September and October 1973, pp.192-95, 243-47; "Statement on the Terminal Professional Degree for Academic Librarians," Chicago: ACRL, 1975.

\section{Standard 5: Service}

5 The library shall establish and maintain a range and quality of services that will promote the academic program of the institution and encourage optimal library use.

\section{Commentary}

The primary purpose of college library service is to promote and support the academic program of the parent institution. Services should be developed for and made available to all members of the academic community, including the handicapped and non-traditional students. The successful fulfillment of this purpose will require that librarians work closely with classroom faculty to gain from them a clear understanding of their educational objectives and teaching methods and to communi- cate to them an understanding of the services and resources which the library can offer. While research skills and ease of access to materials will both serve to encourage library use, the primary motivation for students to use the library originates with the instructional methods used in the classroom. Thus, close cooperation between librarians and classroom instructors is essential. Such cooperation must be a planned and structured activity and requires that librarians participate in the academic planning councils of the institution. They should assist teaching faculty in appraising the actual and potential library resources available, work closely with them in developing library services to support their instructional activities, and keep them informed of library capabilities.

5.1 The library shall provide information and instruction to the user through a variety of techniques to meet differing needs. These shall include, but not be limited to, a variety of professional reference services, and a bibliographic instruction program designed to teach users how to take full advantage of the resources available to them.

\section{Commentary}

A fundamental responsibility of a college library is to provide instruction in the most effective and efficient use of its materials. Bibliographic instruction and orientation may be given at many levels of sophistication and may use a variety of methods and materials, including course-related instruction, separate courses with or without credit, and group or individualized instruction.

Of equal importance is traditional reference service wherein individual users are guided by librarians in their appraisal of the range and extent of the library resources available to them for learning and research. Professional services should optimally be available all hours the library is open. Use patterns should be studied to determine those times when lack of professional help would be least detrimental. The third major form of information service is the delivery of information itself. Although obviously inappropriate in the case of student searches which are purposeful segments of classroom assign-

\section{FORMULA B-}

The number of librarians required by the college shall be computed as follows (to be calculated cumulatively):

For each 500 , or fraction thereof, FTE students up to 10,000

For each 1,000, or fraction thereof, FTE students above 10,000

For each 100,000 volumes, or fraction thereof, in the collection

For each 5,000 volumes, or fraction thereof, added per year
1 librarian

1 librarian

1 librarian

1 librarian

For additional factors to be considered, see Standard 4.3.

Libraries which provide 90-100 percent of these formula requirements can, when they are supported by sufficient other staff members, consider themselves at the A level in terms of staff size; those that provide 75-89 percent of these requirements may rate themselves as $B$; those with 60-74 percent of requirements qualify for a $\mathrm{C}$; and those with 50-59 percent of requirements warrant a $\mathrm{D}$. 
ments, the actual delivery of information-as distinct from guidance to it-is a reasonable library service in almost all other conceivable situations.

Many of the services suggested in this commentary can be provided or enhanced by access to computerized forms of information retrieval. In fact many information sources are available only in computerized format, and every effort should be made to provide access to them. Services may be provided in person or by other measures such as videocassette, computer slide tape, or other appropriately prepared programs.

5.2 Library materials of all types and formats that can be used outside the library shall be circulated to qualified users under equitable policies without jeopardizing their preservation or availability to others.

\section{Commentary}

Circulation of library materials should be determined by local conditions which will include size of the collections, the number of copies, no matter what the format, and the extent of the user community. Every effort should be made to circulate materials of all formats that can be used outside the library without undue risk to their preservation. Circulation should be for as long a period as is reasonable without jeopardizing access to materials by other qualified users. This overall goal may prompt some institutions to establish variant or unique loan periods for different titles or classes of titles. Whatever loan policy is used, however, it should be equitably and uniformly administered to all qualified categories of users. The accessibility of materials can also be extended through provision of inexpensive means of photocopying within the laws regarding copyright.

5.2.1 The quality of the collections shall be enhanced through the use of interlibrary loan and other cooperative agreements.

\section{Commentary}

Local resources should be extended through reciprocal agreements for interlibrary loan according to the ALA codes. Access to materials should be by the most efficient and rapid method possible, incorporating such means as delivery services and electronic mail in addition to, or in place of, traditional forms of delivery. First consideration must always go to the primary users but strong consideration should be given to fostering the sharing of resources.

5.2.2 Cooperative programs, other than traditional interlibrary loan, shall be encouraged for the purpose of extending and increasing services and resources.

\section{Commentary}

The rapid growth of information sources, the availability of a myriad of automation services, and the development of other technologies such as laser beam, videodiscs, microcomputer systems, etc., make new demands on budgets. Cooperation with other institutions, and particularly with multi-type library organizations, often becomes a necessity. It must be recognized that this does not only involve receiving but demands a willingness to give or share on the part of each library. This may mean a commitment of time, money, and personnel, but it is necessary if it is the only way to provide modern services to users. Careful weighing of costs and benefits must be undertaken before such agreements are put into effect.

5.3 The hours of access to the library shall be consistent with reasonable demand.

\section{Commentary}

The number of hours per week that library services should be available will vary, depending upon such factors as whether the college is in an urban or rural setting, teaching methods used, conditions in the dormitories, and whether the student body is primarily resident or commuting. In any case, library scheduling should be responsive to reasonable local need. In some institutions users may need access to study facilities and to the collections, in whole or in part, during more hours of the week than they require the personal services of librarians. However, during the normal hours of operation the users deserve competent, professional service. The high value of the library's collections, associated materials, and equipment, etc., dictates that a responsible individual be in control at all times. The public's need for access to librarians may range upward to one hundred hours per week, whereas around-the-clock access to the library's collection and/or facilities may in some cases be warranted.

5.4 Where academic programs are offered at offcampus sites, library services shall be provided in accord with ACRL's "Guidelines for Extended Campus Library Services."

\section{Commentary}

Special library problems exist for colleges that provide off-campus instructional programs. Students in such programs must be provided with library services in accord with ACRL's "Guidelines for Extended Campus Library Services." These guidelines suggest that such services be financed on a regular basis, that a librarian be specifically charged with the delivery of such services, that the library implications of such programs be considered before program approval, and that courses so taught encourage library use. Services should be designed to meet the different information and bibliographic needs of these users. Such services, which are especially important at the graduate level, must be furnished despite their obvious logistical problems.

\section{Standard 6: Facilities}

6 The library building shall provide secure and 
adequate housing for its collections, and ample well-planned space for users and staff and for the provision of services and programs.

\section{Commentary}

Successful library service presupposes an adequate library building. Although the type of building will depend upon the character and purposes of the institution, it should in all cases be functional, providing secure facilities for accommodating the library's resources, sufficient space for their administration and maintenance, and comfortable reading and study areas for users. A new library building should represent a coordinated planning effort involving the library director and staff, the college administration, and the architect, with the director responsible for the preparation of the building program.

The needs of handicapped persons should receive special attention and should be provided for in compliance with the Architectural Barriers Act of 1968 (Public Law 90-480) and the Rehabilitation Act of 1973, Section 504 (Public Law 93-516) and their amendments.

Particular consideration must be given to any present or future requirements for equipment associated with automated systems or other applications of library technology. Among these might be provision for new wiring, cabling, special climate control and maximum flexibility in the use of space. Consideration should also be given to loadbearing requirements for compact shelving and the housing of mixed formats including microforms.

6.1 The size of the library building shall be determined by a formula (see Formula C) which takes into account the enrollment of the college, the extent and nature of its collections, and the size of its staff.

6.2 In designing or managing a library building, the functionality of floor plan and the use of space shall be the paramount concern.

\section{Commentary}

The quality of a building is measured by such characteristics as the utility and comfort of its study and office areas, the design and durability of its furniture and equipment, the functional interrelationships of its service and work areas, and the ease and economy with which it can be operated and used.

6.3 Except in certain circumstances, the college library's collections and services shall be administered within a single structure.

FORMULA C-

The size of the college library building shall be calculated on the basis of a formula which takes into consideration the size of the student body, the size of the staff and its space requirements, and the number of volumes in the collections. To the result of this calculation must be added such space as may be required to house and service nonprint materials and microforms, to provide bibliographic instruction to groups, and to accommodate equipment and services associated with various forms of library technology.

a. Space for users. The seating requirement for the library of a college where less than fifty percent of the FTE enrollment resides on campus shall be one for each five students. That for the library of a typical residential college shall be one for each four FTE students. Each study station shall be assumed to require 25 to 35 square feet of floor space, depending upon its function.

$b$. Space for books. The space allocated for books shall be adequate to accommodate a convenient and orderly distribution of the collection according to the classification system(s) in use, and should include space for growth. Gross space requirements may be estimated according to the following formula.

For the first 150,000 volumes

Square Feet/Volume

For the next 150,000 volumes

0.10

For the next 300,000 volumes

0.09

For holdings above 600,000 volumes

0.08

0.07

c. Space for staff. Space required for staff offices, service and work areas, catalogs, files, and equipment, shall be approximately one-eighth of the sum of the space needed for books and users as calculated under a) and b) above.

This formula indicates the net assignable area required by a library if it is to fulfill its mission with maximum effectiveness. "Net assignable area" is the sum of all areas (measured in square feet) on all floors of a building, assignable to, or useful for, library functions or purposes. (For an explanation of this definition see The Measurement and Comparison of Physical Facilities for Libraries, American Library Association, 1970.)

Libraries which provide 90 to $100 \%$ of the net assignable area called for by the formula shall be graded A in terms of space; $75-89 \%$ shall be graded B; $60-74 \%$ shall be graded $\mathrm{C}$; and $50-59 \%$ shall be graded D. 


\section{Commentary}

Decentralized library facilities in a college have some virtues, and they present some difficulties. Primary among their virtues is their convenience to the offices or laboratories of some members of the teaching faculty. Primary among their weaknesses is the resulting fragmentation of the unity of knowledge, the relative isolation of a branch library from most users, potential problems of staffing and security, and the cost of maintaining certain duplicative services or functions. When decentralized library facilities are being considered, these costs and benefits must be carefully compared. In general, experience has shown that decentralized library facilities may not be in the best academic or economic interest of a college.

\section{Standard 7: Administration}

Matters pertaining to college library administration are treated in the several other Standards. Matters of personnel administration, for example, are discussed under Standard 4, and fiscal administration under Standard 8. Some important aspects of library management, however, must be considered apart from the other Standards.

7 The college library shall be administered in a manner which permits and encourages the fullest and most effective use of available library resources.

\section{Commentary}

The function of a library administrator is to direct and coordinate the components of the library-its staff, services, collections, building and external relations-so that each contributes effectively and imaginatively to the mission of the library.

7.1 The statutory or legal foundation for the library's activities shall be recognized in writing.

\section{Commentary}

In order for the library to function effectively, there must first be an articulated understanding within the college as to the statutory or legal basis under which the library operates. This may be a college bylaw, a trustee minute, or a public law which shows the responsibility and flow of authority under which the library is empowered to act.

7.2 The library director shall be an officer of the college and shall report to the president or the chief academic officer of the institution.

\section{Commentary}

For the closest coordination of library activities with the instructional program, the library director should report either to the president or the officer in charge of the academic affairs of the institution.

7.2.1 The responsibilities and authority of the library director and procedures for appointment shall be defined in writing.

\section{Commentary}

There should be a document defining the responsibility and authority vested in the office of the library director. This document may also be statutorily based and should spell out, in addition to the scope and nature of the director's duties and powers, the procedures for appointment.

7.3 There shall be a standing advisory committee comprised of students and members of the teaching faculty which shall serve as a channel of formal communication between the library and its user community.

\section{Commentary}

This committee-of which the library director should be an ex officio member - should be used to convey both an awareness to the library of its users' concerns, perceptions and needs, and an understanding to users of the library's objectives and capabilities. The charge to the committee should be specific and in writing.

7.4 The library shall maintain written policies and procedures manuals covering internal library governance and operational activities.

\section{Commentary}

Written policies and procedures manuals are required for good management, uniformity, and consistency of action. They also aid in training staff and contribute to public understanding.

7.4.1. The library shall maintain a systematic and continuous proqram for evaluating its performance, for informing the community of its accomplishments, and for identifying needed improvements.

\section{Commentary}

The library director, in conjunction with the staff, should develop a program for evaluating the library's performance. Objectives developed in accordance with the goals of the institution should play a major part in this evaluation program. Statistics should be maintained for use in reports, to demonstrate trends, and in performance evaluation. In addition, the library director and staff members should seek the assistance of its standing library advisory committee and other representatives of the community it serves.

7.5 The library shall be administered in accord with the spirit of the ALA "Library Bill of Rights."

\section{Commentary}

College libraries should be impervious to the pressures or efforts of any special interest groups or individuals to shape their collections and services. This principle, first postulated by the American Library Association in 1939 as the "Library Bill of Rights," (amended 1948, 1961, and 1967 by the ALA Council) should govern the administration of every college library and be given the full protection of the parent institution. 


\section{Standard 8: Budget}

8 The library director shall have the responsibility for preparing, defending, and administering the library budget in accord with agreed upon objectives.

\section{Commentary}

The library budget is a function of program planning and defines the library's objectives in fiscal terms. The objectives formulated under Standard 1 should constitute the base upon which the library's budget is developed.

8.1 The library's appropriation shall be six percent of the total institutional budget for educational and general purposes.

\section{Commentary}

The degree to which the college is able to fund the library in accord with institutional objectives is reflected in the relationship of the library appropriation to the total educational and general budget of the college. It is recommended that library budgets, exclusive of capital costs and the costs of physical maintenance, not fall below six percent of the college's total educational and general expenditures if it is to sustain the range of library programs required by the institution and meet appropriate institutional objectives. This percentage should be greater if the library is attempting to overcome past deficiencies, or to meet the needs of new academic programs.

Factors which should be considered in formulating a library's budget requirements are the following:

1. The scope, nature and level of the college curriculum;

2. Instructional methods used, especially as they relate to independent study;

3. The adequacy of existing collections and the publishing rate in fields pertinent to the curriculum;

4. The size, or anticipated size, of the student body and teaching faculty;

5. The adequacy and availability of other library resources;

6. The range of services offered by the library, for example, the number of service points maintained, the number of hours per week that service is provided, the level of bibliographic instruction, online services, etc.;

7. The extent of automation of operations and services, with attendant costs;

8 . The extent to which the library already meets the College Library Standards.

8.1.1 The library's appropriation shall be augmented above the six percent level depending upon the extent to which it bears responsibility for acquiring, processing, and servicing audiovisual materials.

\section{Commentary}

It is difficult for an academic library that has not traditionally been purchasing audiovisual materials to accommodate such purchases without some budgetary increase. The level of expenditure depends upon whether or not the institution has an audiovisual center separate from the library that acquires and maintains both audiovisual materials and hardware.

8.2 The library director shall have sole authority to apportion funds and initiate expenditures within the library budget and in accord with institutional policy.

\section{Commentary}

Procedures for the preparation and defense of budget estimates, policies on budget approval, and regulation concerning accounting and expenditures vary from one institution to another. The library director must know and conform to local procedure. Sound practices of planning and control require that the director have sole responsibility and authority for allocation-and within college policy, the reallocation - of the library budget and the initiation of expenditures against it. Depending upon local factors, between $35 \%$ and $45 \%$ of the library's budget is normally allocated to acquisition of resources, and between $50 \%$ and $60 \%$ is expended for personnel.

8.3 The library shall maintain internal accounts for approving its invoices for payment, monitoring its encumbrances, and evaluating the flow of its expenditures.

\section{Commentary}

Periodic reports are necessary and provide an accurate account of the funds allocated to the library. They should be current and made accessible for fiscal accountability.

\section{Appendix \\ Other works cited}

American Library Association, Ad Hoc Committee on the Physical Facilities of Libraries. Measurement and Comparison of Physical Facilities for Libraries. Chicago: ALA, 1970.

"[ACRL] Guidelines and Procedures for the Screening and Appointment of Academic Librarians." C\&RL News, September 1977, pp. 231-33.

"[ACRL] Guidelines for Extended Campus Library Services." C\&RL News, March 1982, pp. 86-88.

"[ACRL] Model Statement of Criteria and Procedures for Appointment, Promotion in Academic Rank, and Tenure for College and University Librarians." C\&RL News, September and October 1973, pp. 192-95, 243-47.

"[ACRL] Standards for Faculty Status for College and University Librarians." C\&RL News, May 1974, pp. 112-13.

"[ACRL] Statement on the Terminal Professional Degree for Academic Librarians." Chicago: 
ALA/ACRL, 1975.

"Library Bill of Rights" (ALA Policy Manual, Section 53.1). In the ALA Handbook of Organization 1984/85. Chicago: ALA, 1984, pp. 217-18.

Library Education and Personnel Utilization: A
Statement of Policy. Adopted by ALA Council. Chicago: ALA/OLPR, 1970.

[RASD/IFLA] Interlibrary Loan Codes, 1980; International Lending Principles and Guidelines, 1978. Chicago: ALA, 1982.

\section{Cooperative Collection Development}

About 180 librarians and representatives of state higher education and library agencies from 40 states and Canada gathered at Chicago's Bismarck Hotel on April 1-2 to participate in building a model statewide plan that can be used in coordinating library cooperative collection development.

Supported in part by a grant from the Illinois Board of Higher Education, the symposium featured speakers from every identified formalized state, regional, or national plan.

Following every two or three speakers, the audience took part in a discussion of the plans with facilitators who had read the papers in advance. The discussion leaders were members of the Illinois Association of College and Research Libraries (IACRL)/Illinois Board of Higher Education (IBHE) Cooperative Collection Development Committee, and it was this group that developed criteria for a model statewide plan at the end of the symposium.

Speakers at the symposium included Robert Wallhaus, deputy director for academic affairs at the Illinois Board of Higher Education, who described the Illinois experience; and Paul Mosher, director of resource services at Stanford, who provided background on the Research Libraries Group/North American Collection Inventory Project effort to coordinate collection development and management on a national level. Other speakers described the state plans in Indiana, Illinois, Colorado, California, and New York; intra-state plans, such as the Triangle Research Libraries Network and the Hampshire Inter-Library Center; and inter-state plans, such as the Alaska Cooperative Collection Development Project and the Pacific Northwest Collection Assessment Project.

The proceedings of the symposium, including the IACRL/IHBE Committee's model statement, will be published in RESIN (Resource Sharing and Information Networks) and as a monograph by the Haworth Press, scheduled to appear by the end of this year.

According to Wilson Luquire, symposium coordinator and dean of library services at Eastern Illinois University, another symposium may be held two or three years from now to chart the progress of the various state and regional plans.

\section{Sandra Donnelly is ACRL's new CE officer}

Sandra Donnelly has been appointed ACRL continuing education program officer effective April 23. Her most recent position was as manager for continuing education programs in health and human services at the College of DuPage, Downers Grove, Illinois, where she assessed the training needs of the health and human service audience and developed and implemented seminars in technology. She also spent a fivemonth internship at the City Colleges of Chicago planning programs

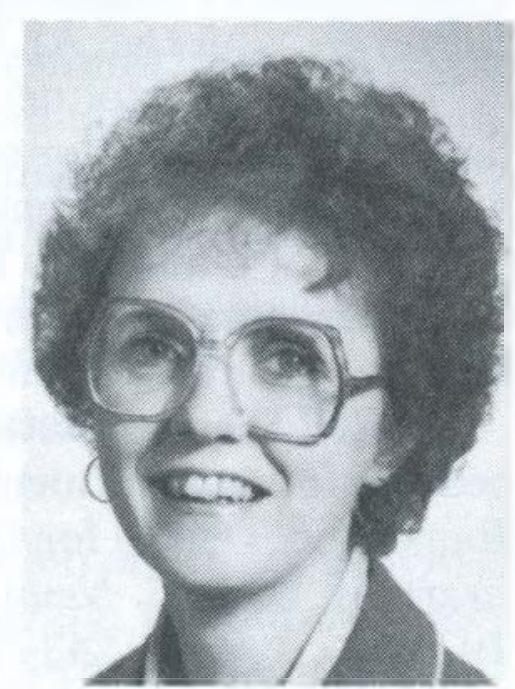

Sandra Donnelly in non-credit adult continuing education. She holds a master's degree in adult continuing education from Northern Illinois
University.

In her work for ACRL, Donnelly has three responsibilities. She supervises the development and production of courses given at ALA and ACRL conferences. She is also staff liaison for ALA's Divisional Leadership Enhancement Program, the final phase of which will be held at Annual Conference in Chicago. And she serves as co-director of the project on humanities programming, cosponsored by the National Endowment for the $\mathrm{Hu}$ manities, the Public Library Association, and ACRL.

\section{Erratum}

In Table I of Richard Smith's article, "Mass Deacidification Cost Comparisons," on page 123 of the March 1985 issue of $C \& R L$ News, the original equipment cost for the Library of Congress system should have been $\$ 11,500,000$. 


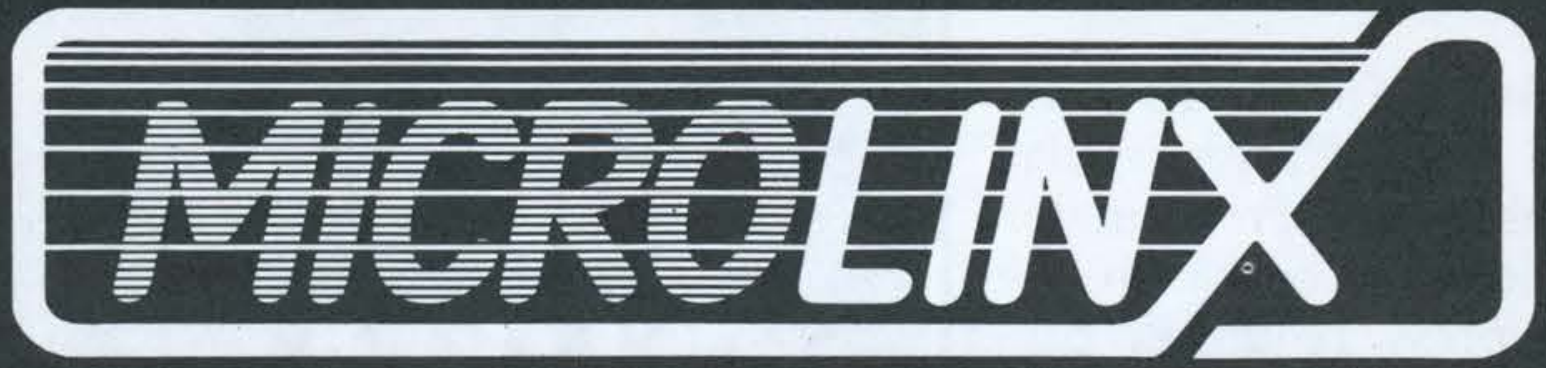

A Microcomputer Based Serials Control System

Call Us. 


\section{ACQUISITION PERSPECTIVES}

2. Book House guarantees to order each book you request, with regular claiming to publishers. From major publishers on open account to the most obscure press requiring prepayment and offering no discount, our persistence and experience enables us to deliver every available title.

There is no substitute for complete delivery.

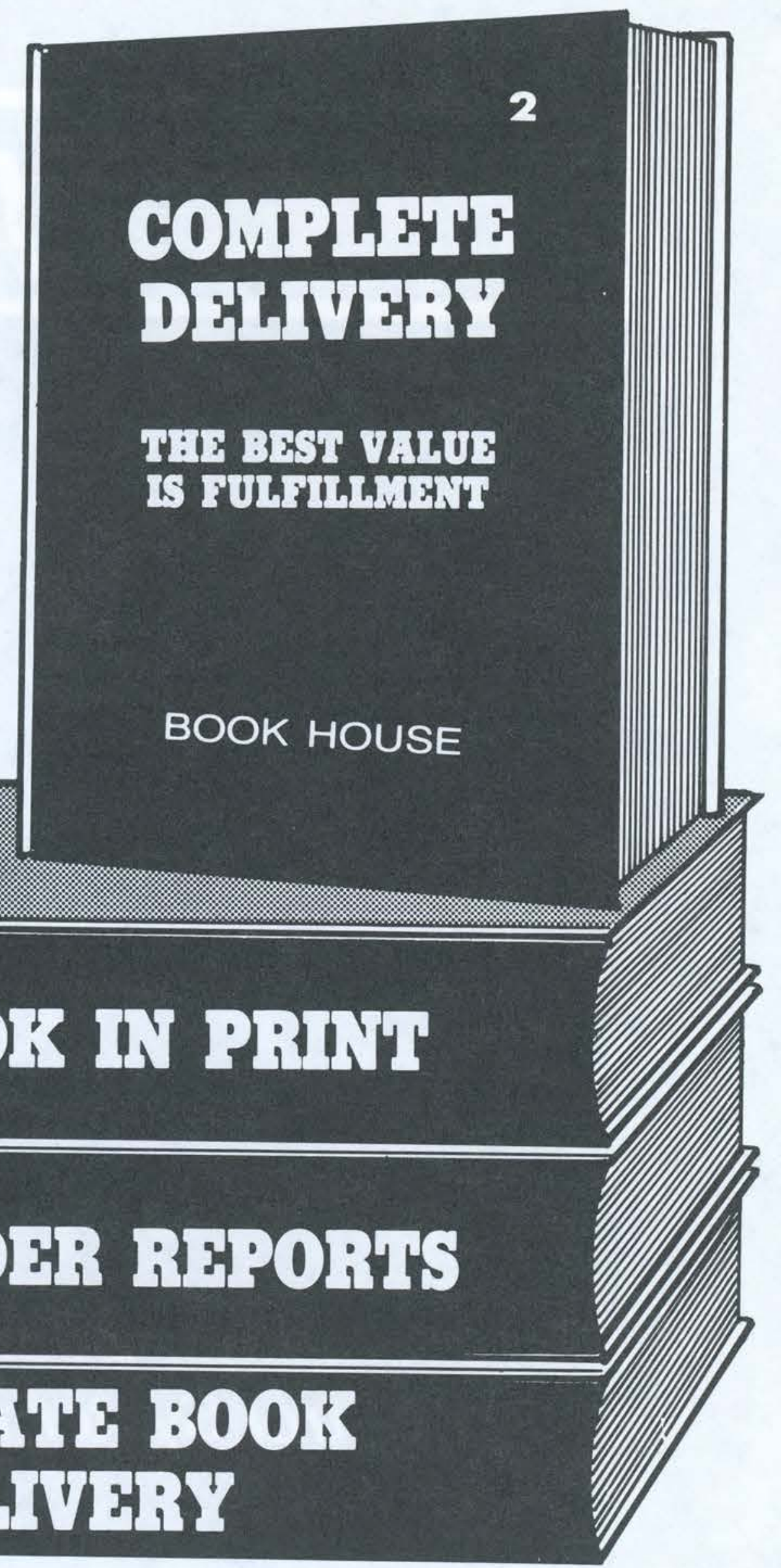

\section{CALL TOLL-FREE TODAY \\ 1-800-248-1146}

In Canada \& Michigan

CALL COLLECT (517) 849-2117

OCLC Vendor No. 17397

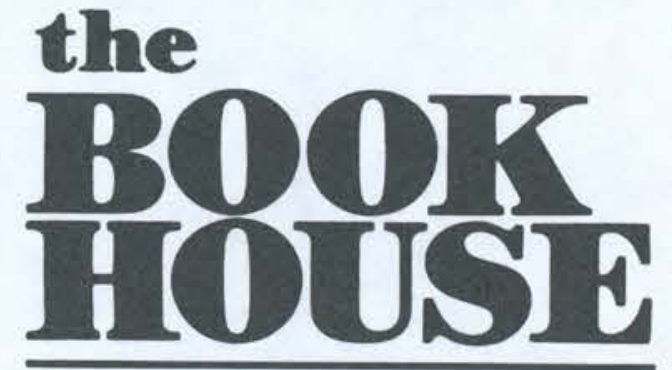

JOBBERS SERVING LIBRARIES WITH ANY BOOK IN PRINT SINCE 1962 208 WEST CHICAGO STREET JONESVILLE, MICHIGAN 49250 